\title{
Uses of the Imagination: Bilanguaging the Translation of U.S. Latino Poets
}

\author{
Lisa Rose Bradford, \\ Universidad Nacional de Mar del Plata
}

\begin{abstract}
Pompeii and the Uses of Our Imagination [...]

I closed my eyes and imagined a huge tamale Run over by mole sauce, my only reference To a thing that got smothered. On top of this tamale, A chariot, crowned Gods, an emperor in a white robe. [...] Yul Brynner, Tony Curtis, and Kirk Douglas, My heroes! They were going to fight the lava, Push it back. But they slipped on the mole sauce, $[\ldots]$

Gary Soto
\end{abstract}

Translation is a slippery business, powdery snow on black ice-or mole on a tamale, as it were-for it compounds the problems of the inherent instability of language with the unruly process of duplicating it in another system. To use the words of Stephen Greenblatt: "Language is the slipperiest of human creations; like its speakers, it does not respect borders, and, like the imagination, it cannot ultimately be predicted or controlled" (62). The lack of borders becomes particularly daunting in the translation of multicultural poetry since the distance from "the norm" becomes even greater. This is true firstly because poetry is a genre that strives for verbal concision and innovation in a playful defiance of norms that piques the reader's imagination; and secondly because the multilingual poet involves a second language-either in its original form or as a translation into the language of composition - to enhance sound and cultural imagery and to challenge normative discourse. The humour and pathos deriving from the conceptual chaos found in the poem cited above is typical of Latino poetry, which generally glides along on the linguistic and cultural tension inherent in both its poeticity and its English/Spanish and Latino/Anglo dualities. Therefore, the translation of this verse must also produce a similarly slippery tension for the reader, a task that Fabián Iriarte and I constantly grappled with in the editing of a recent bilingual anthology, Usos de la imaginación: poesía de l@s latin@s en EE.UU. This paper contains a reconstruction of the path we took in order to translate the poems for this compendium, 
which leads to various theoretical propositions both for future translation work as well as for Translation Studies and Comparative Literature.

This book began as an experiment in heterolingual translation in general, and after selecting eleven Latino poets for an anthology-Rafael Campo, Judith Ortiz Cofer, Silvia Curbelo, Martín Espada, Diana García, Richard García, Maurice Kilwein Guevara, Juan Felipe Herrera, Pat Mora, Gary Soto and Gloria Vando-we spent two years researching and rehearsing versions in readings and seminars offered in universities in Mar del Plata and Córdoba in order to test the success of our translation strategies ${ }^{1}$.

Our main theoretical grounding for this work is linked to a notion developed by Walter Mignolo. This critic, known for his research on postcolonial issues, coined the term "languaging" to discuss a process which he defines as: "[...] that moment between speech and writing, before and after language, that languages make possible" (253). He goes on to theorize that bilanguaging, "as a condition of border thinking from the colonial difference, opens up to a postnational thinking" (254). The creativity and the ethnic marking involved in "bilanguaging" have, within the last few decades, inspired many authors to engage in diglossic representation so as to regenerate their bicultural identities in works that move beyond their national locations.

There were, however, many aspects to be considered before deciding on the best approach to translating this verse. To begin with, we researched different modes of polygossia; then we examined the tradition of multicultural and multilingual literature in general and analyzed various attempts to translate it and to theorize about it; and finally, we attempted to define the ideology behind different usages of multilingualism in our Latino texts in order to recast each poet's strategies in the Spanish translations. This meant locating the heteroglossic particulars of Latino poetry or poetries - the Latino categorization is, admittedly, a dubious umbrella in many ways -in order to determine how these features could be kept visible in the new versions.

\section{Heteroglossia in Literature}

The concept of "heteroglossia" is particularly valuable in our discussion on Latino poetics. The following quotation from The Dialogic Imagination defines Bakhtin's use of the term:

\footnotetext{
${ }^{1}$ This project was funded by the Agencia Nacional de Promoción Científica y Tecnológica.
} 
Closely connected with the problem of polyglossia and inseparable from it is the problem of heteroglossia within a language, that is, the problem of internal differentiation, the stratification characteristic of any national language. This problem is of primary importance for understanding the style and historical destinies of the modern European novel, that is, the novel since the seventeenth century. This latecomer reflects, in its stylistic structure, the struggle between two tendencies in the languages of European peoples: one a centralizing (unifying) tendency, the other a decentralizing tendency (that is, one that stratifies languages). The novel senses itself on the border between the completed, dominant literary language and the extraliterary languages that know heteroglossia. (67)

Though Bakhtin created this term in order to discuss the nineteenth-century Russian novel, contemporary poetry has also become dialogical in its use of personae and citation, and multicultural poetry even more so as it often integrates at least two strata of language-either as heterolingualism or implicit translation-in its multicultural thrust, which is an essential feature of Latino poetics. Apart from the terms "heteroglossia" and "polyglossia," there are many names for the multilingual tension found in such texts: diglossia, non-convergent discourse, language converging and merging, code switching, etc. In oral discourse, the most prevalent terminology at present is that of code switching. Basically, this is a label applied to a cross-cultural interaction between people who speak at least two languages and thus feel at ease using words from both languages, not only through borrowing but also through a morphological or syntactical adaptation of words - for the most part nouns and verbsto the base language that is being spoken. This may stem from insufficient knowledge of the languages in use, an inability to locate the precise word in the main tongue, an ethnic marking to stress a cultural belonging, or the creative wit of pure wordplay.

Multicultural texts have, of course, existed for centuries as can be easily seen in the macaronic poems from ancient to present times, the multilingual works of the Middle Ages, and the regionalist books of the nineteenth and twentieth centuries. In all of these cases, though there does exist a specific and distinct rationale behind each use of polyglossia-which depends upon the writer, glosser, and/or reader of the work-the transportation of these texts into different ages and cultures becomes an arduous and sometimes impossible task that hinges first upon the rationalization of the source's usage, and second, upon the availability of conventions within the receiving language.

A brief excursus to an interesting text from the middle ages may help us understand the different appearances of heteroglossic texts through time. According to 
studies currently underway by European medievalists ${ }^{2}$, even though late eleventh- and twelfth-century manuscripts demonstrate a mixed-language environment, for the most part they were written, annotated or glossed in one single language, depending upon the audience. An interesting case of a historical text has been discussed by Elizabeth Tyler in her study, "Talking about history in eleventh-century England: the Encomium Emmae Reginae and the court of Harthacnut." Written by a clerical confidant, this history was commissioned by Queen Emma of Normandy and conceived in order to exalt the virtues of King Cnut and thus her progeny. Composed in a period of vernacularization (English, Norse, French, and Flemish), it was created in Latin so as to negotiate the political differences of the time. Nevertheless, the oral transmission of the story would have been performed in one or more of the vernaculars. Though an intermingling of multiple cultural systems is present, the text is already "translated" in its very writing since Latin was no one's mother tongue and therefore non-factional. One might say that the translation of the text took place in its original writing, therefore assuring the accessibility of the history through the ages while avoiding a cultural domination which would have been implicit in choosing one of the vernacular tongues over another ${ }^{3}$.

There also exist artistic variations of polyglossia in former times, variations which may, in fact, be artificial or affective devices that do not imitate a merging of languages but rather celebrate the possibility of switching languages to create a storehouse of novel figures. In fact, if we think about one of the more obvious uses of multilingualism in literature, the macaronic poem certainly comes to mind. The witty effect of these poems often relies upon the dueling nature of the languages by exposing the pratfalls and advantages of using one or the other along with the potential of mirroring rhetorical effects in two separate languages. Though some of these texts have been glossed, translations must often prove either redundant or else become rewritings that underscore the playful patterning, regardless of semantics.

\footnotetext{
${ }^{2}$ I would like to thank Mary Swan from the University of Leeds and Elizabeth Tylor from the University of York for their guidance in this matter.

${ }^{3}$ There do exist actual multilingual texts in the Middle Ages. For example, multilingualism in the legal texts, such as in the case of the legal writs on property transfer, which have a traceable rationale: while the Latin replicates the forms inherited from Rome, the actual geographical limits of the propertiesrivers, hills, etc-are written in Anglo-Saxon, apparently to ensure the location of areas as were known in the vernacular to avoid any discrepancy. Other multilingual texts include copies of manuscripts which were glossed in the transcription, tending toward a multilingual version of the text, produced to explicate their meaning and create vernacular forms of the Latin: a writ by King Edward, c 1052-66 (Harmer 1952, nr 34)
} 
A propos of the translation of multilingual Renaissance works, in a poem such as Dante's The Divine Comedy, where the strategy behind the use of the Provençal is one of geographical, character, and literary marking, we see that it is customary to translate both the Italian and the Provençal into one single language, adding a note or an appendix providing the Provençal, but never juxtaposing the two languages. This practice reflects the assumption that modern-day readers are, and, in fact, postRenaissance readers were, for the most part, monolingual.

In The Dialogic Imagination, Bakhtin cites the "interanimation of languages" as an integral part of literary creation in this period of transition to monolingualism: "only polyglossia fully frees consciousness from the tyranny of its own language and its own myth of language" (61). In his study "The Prehistory of the Novel" he describes the preRenaissance situation when Roman literary consciousness was bilingual and authors wrote "though the eyes of the Greek word" (61). He goes on to describe the change that took place during the Renaissance involving the "ideological language (Latin) and the move of the European peoples toward the critical monoglossia characteristic of modern times" (68). Owing to the parodic-transformative character of words, according to Bakhtin, we are still able to recontextualize, and thus resignify with our language, dialogical processes exacerbated in many postmodern and postcolonial works.

Poets' minds are not entirely monolingual and thus there have always been writers who ponder other languages within their works, creating instances of implicit polyglossia. One example of this can be found in a poem by a translator of Spanish, Stephen Kessler. His poem "Second Language" plays with the Spanish word "tocar" which means both to touch and to play an instrument: "To touch, in this tongue, is to play, as in: / I touch the keys of the machine and music emerges" (1). The entire poem alludes to the constellations of meaning produced by this Spanish word without ever writing it. However, its translation into Spanish would be somewhat deflating since the second language would become the first, and thus a translation of the way the poem means would demand the use of an entirely different word from English that could embody this playful richness in such a way that it could be a pebble forming ripples of meditation for a Spanish reader.

The nature of heteroglossia in our Latino poets varies greatly from poet to poet and poem to poem. However, one common denominator can be found in their inclusion of language from their Hispanic backgrounds, which they recontextualize and, thus, resignify within their verse. The richness of music, food, and specific words - for their 
euphony or circumstance-functions as an indicator of an "other" culture used to configure the hybrid nature of their experiences.

\section{Translating Heteroglossia}

We may ask, are these allusions to other languages any different from literal polyglossia as regards their translatability? They render a mixed language mind set by means of interanimation and heteroglossia in evoking other tongues, but their translations run the risk of losing the wit and linguistic compression, as is the case in most culturally implicit allusions, whether they be of an intertextual or intercultural nature. However, appropriation, reappropriation, intertextuality or the inversion of another's discourse through parody will always be read as modes of both constituting poetics and reflecting upon language, and this is why a translation of these works must weigh this intermingling in order to achieve a second version that successfully transmits the dynamics of the text.

In order to understand the nature of the linguistic interanimation of Latino poetics, certain notions developed by Indian critic Homi Bhabha provide some insight. Citing the power of a "migratory vision" derived from heteroglossic strategies, Bhabha has generated a highly suggestive argument in favour of heterolingual techniques in his book The Location of Culture. He discusses the provocative potential of creating a multicultural vision that represents a reality of interstices, situations inherent in immigrant or postcolonial living beyond paradigmatic limits. Grounding his arguments on translation and its sense of the hybridity of imagined or rewritten communities, Bhabha speaks of negotiating certain values by constructing a "catachrestic space." Resorting to this rhetorical trope, he suggests that one can wrest the canonic meaning from "narratives of originary and initial subjectivities" in order to resignify with innovative combinations of discourse through an incommensurable and insurgent "unpicking" and relinking that can be produced by retranslating normative discourses (185).

Latino poetry shares this tendency to retranslate and relink in its use of Spanish elements, so it not only is heteroglossic in the friction present between different linguistic and cultural strata, but is also heterolinguistic. Forming an essential ingredient, this heterolingualism derived from the mixing of English and Spanish must be rendered in a successful translation, but how can this be accomplished in a Spanish version, which would intrinsically neutralize the harmony or dissonance of this bilingual tension and thus homogenize the text? 
According to Canadian critic Rainier Grutman in his article "Refraction and recognition: Literary multilingualism in translation," there exist two basic ways to translate these texts: either they are domesticated by creating a homogeneous monolingualism, or they become what some label "an atrocious bilingual hybrid" ${ }^{4}$. One traditional method for resolving this problem is to leave the foreign word and place a translation of it in parentheses or in an appendix. Another way, in the case of translating a text into the second language, is to highlight the originally foreign word by means of italics of boldface print ${ }^{5}$.

In the article, "Code-switching and code mixing in African creative writing. Some insights for Translation Studies," Paul Bandia thoroughly synthesizes the pragmalinguistic scholarship on the phenomenon of code switching and documents and categorizes usages in African literature to then make a case for "authentic renditions" of creolizations in different tongues. However, he also points out that the language mixing often involves "in-text translation" to avoid glossaries or footnoting, a situation that is highly artificial and intrusive and moves the emphasis from representationality to sociocultural relevance. Therefore, one finds that the use of "other" languages in the text often has more to do with the establishment of authority and identity than verisimilitude.

Meir Steinberger has also created useful categories for the study of polylingual representation. His classification helps distinguish different conventions for writing practices: 1. referential restriction (suppressing all linguistic differences); 2 . vehicular matching (the use of each language as corresponds to the characters' realities); and 3. homogenizing convention (a linguistic synecdoche, a word or phrase to represent a totality). This third category is most helpful for our work with Latino poets. The intermingling of Spanish and English in the U.S., despite attempts to legitimize "Spanglish" as a language, does not constitute a stable creolization since the bilanguaging is both creative and spontaneously improvised for the most part, and its vocabulary depends on the national roots of the speaker. Therefore, it is useful to consider Spanish words in U.S. Latino literature as metonymic or synecdochic because Latino writers employ parts of the language-sounds, words, textures-as the power

\footnotetext{
${ }^{4}$ In this article, Grutman cites Keith Garebian in his reference to a translation by Ray Ellenwood (38).

${ }^{5}$ Cf. in my paper "Translation a 'Migratory Vision'” Section 6, Translation, Tradition, Betrayal? Gendered Agencies in Translation Theory and Practice. ICLA-Rio de Janeiro. CD, July, 2007, I discuss three modes of translation in Sandra Cisnero's "Woman Hollering Creek" and Ernest Hemingway's For Whom the Bell Tolls by means of italics, boldface and compensation according to translation and authorial habitus.
} 
and presence of the culture they embody. There is a crafting of the two languages, rather than a representation of authentic discourse, and this underscores issues of cultural identity because the heteroglossic expression perplexes the reader and thus presents a meaningful resistance.

\section{Bilanguaging the Translations of Latino Verse}

Though Hispanic voices in the U.S. vary greatly since this community arises from different geographic, economic, professional and political origins, they all have a propensity to represent an "otherness" within the ambiguity and ambivalence of a bilingual and bicultural reality. In their poetry, this appears as a translation in a broad sense-mistranslation, retranslation, and/or zero translation-used in order to liberate and flaunt a bilingual imagination. Some consider this bicultural situation as a contradiction, as a "colonization of the mind" (Ngugi wa Thiongo) imposed by U.S. educational practices, while others take advantage of it in order to "bilanguage" reality and so destabilize the monolingual vision of the U.S and highlight the incommensurability of the different cultures as a political commentary.

Geographic migratory movements are reflected in works of these poets: from California to the Carolinas in the harvests and canneries or mills, and steel and factory jobs from Chicago to Detroit. Many second and third generation Latinos have university degrees, and in their verse, they tend to juxtapose their realities with those of their parents. Although the physical movements and realities are different, certain common topics emerge from their bicultural situations - the immigrant's poverty, the color of their skin, their Catholic legacy and general culture clashes and misunderstandings. Also, there exists a preponderant, underlying humor in most poems that serves as an antidote for possible sentimentality. Their poetics are largely based on dialogism, montage and orality; in fact, much of the poetry is written for recitation. To achieve this level of colloquial dialogism, they often represent the linguistic tension that stems from their bilingualism by recreating dialogues with Anglos or with their immigrant relatives, and, in doing so, they intensify the heteroglossia of the texts.

Our translation mode was not based only on semantics, but rather on the flow and wit of each poem in order to find a way to emulate the overarching dialogism of the poetry. Though an original trope may "get lost in translation," we endeavoured to compensate with a new brilliance and playfulness that the Spanish language afforded so as to defog the window of transfer and let the colours of the tropes shine completely 
through. Being colloquial in expression, these poems were, in most cases, rendered in Argentine idioms since our readers will mainly be "Rioplatenses," those who live in the major cosmopolitan areas of Argentina and Uruguay. We believe the intimacy produced in the conversational tone of the poems is best conveyed with a spoken language and not some artificial "Panhispanic" invention. In using Argentine vocabulary, we also chose to employ the characteristic "vos" instead of "tú" for the informal second person singular.

When translating instances of heterolingualism, we often had to judge how to compensate according to each poem: in some cases, the original words were placed in italics, particularly in titles; while in others, English words were used within the poems to emulate the bilingual tension. Furthermore, in making the anthology bilingual, we challenged the monolingual mode of publication, offering en face typographic evidence that actually displays the differences and invites a comparison of versions. It is our hope that the reader will enjoy the possibility of detecting the shifts and locating the original heterolingual strategies.

When dealing with the obstacles involved in regenerating the Latino bicultural identity in Spanish translation, we also had to consider the fact that the original Hispanic culture was never Argentine; therefore, in the cases where heterolingualism dominated, we decided that the vocabulary required a register different from that of the River Plate region and, thus, we utilized terms from the Caribbean or Mexico as well as the informal singular you-tú-instead of the Argentine "vos" in those particular poems.

\section{Cases and Categories}

In order to examine some of the problems and possible solutions in the translations of heteroglossic texts, the works of a few of the poets from our collection may serve as constructive examples to answer the question: how does one transfer these bicultural elements created for an English reader into a version to be read by a monolingual Spanish reader?

Chicana poet Pat Mora provides particularly useful insights. Born in the El Paso/Juárez zone of Texas, this borderland poet grew up in a Hispanic lifestyle in a bicultural area of an "other" country; that is, she lived as a Hispanic ruled by U.S. hierarchies. Therefore, she finds herself standing in the doorway between two very different worlds, as she configures in the poem "Sonrisas." (142): 


\author{
I live in a doorway \\ between two rooms. I hear \\ quiet clicks, cups of black \\ coffee, click, click like facts: \\ budgets, tenure, curriculum, \\ from careful women in crisp beige \\ suits, quick beige smiles \\ that seldom sneak into their eyes. \\ I peek \\ in the other room señoras \\ in faded dresses stir sweet \\ milk coffee, laughter whirls \\ with steam from fresh tamales \\ sh, sh, mucho ruido, \\ they scold one another, \\ press their lips, trap smiles \\ in their dark, Mexican eyes.
}

Our Spanish version makes use of both italics and English to represent the bicultural situation. The title is in Spanish, and as such we placed it in italics to signal the foreignness, as is the case in the second stanza with the Spanish interjection. In a counterpoised balance, the two stanzas invite comparison and contrast: how the "women" and "señoras" take their coffee, how they dress, what they discuss and finally their smiles. We strove to capture the quick, dry sound qualities of the stirring and the suits of the "Anglos" using typical terminology for board meetings in Argentine universities, but we included "tenure" in italics as a recognizable U.S. cultureme ${ }^{6}$ in order to recreate the idiomatic and cultural tension. We also intensified the contrast between the two groups by using the word "caseros" (homemade) instead of "frescos" (fresh) when referring to the tamales to connote their traditional family values.

\title{
Sonrisas
}

\footnotetext{
${ }^{6}$ Nord (1997) develops the concept of culturemes to signify culture specific phenomena or cultural markers. They can be intertextualities or words that allude to an entire narration embedded in the popular imagination. In this case, tenure is culturally specific to the U.S. system of higher education.
} 
Vivo en el lintel

entre dos salas. Escucho

el clic de tazas de café negro, clic clic como datos:

presupuestos, tenure, planes de estudio de cautas mujeres trajecito sastre color beige, ligeras sonrisas color beige que pocas veces llegan a sus ojos

de reojo veo en la otra sala, a señoras con vestidos desteñidos que revuelven el azúcar en su café con leche, risas en remolinos del vapor de tamales caseros sh sh, mucho ruido

se retan una a otra, dedo contra labios, atrapan sonrisas en sus oscuros ojos mejicanos.

In a rich display of sensual and sensorial imagery, Mora often addresses feminine issues surrounding the workplace and home to probe maternal and amorous relationships. Her main focus is on the multicultural and ecological diversity of the U.S., and she tends to situate her poems in desert, Indian and/or Latino spaces within a dialogical style of conversations and intertextualities using graphical placement to enhance the hiatic phenomenon of her reality:

\section{Bilingual Christmas}

Do you hear what I hear?

Buenos días and hasta luego

in board rooms and strategy sessions.

Where are your grateful holiday smiles,

bilinguals? I've given you a voice,

let you in

to hear old friends tell old jokes.

Stop flinching. Drink eggnog. Hum along.

Not carols we hear, 


$$
\begin{aligned}
& \text { whimpering, } \\
& \text { children too cold } \\
& \text { to sing } \\
& \text { on Christmas eve. }
\end{aligned}
$$

Do you see what I see

adding a dash of color

to conferences and corporate parties

one per panel or office

slight South-of-the border seasoning

feliz navidad and próspero año nuevo, right?

Relax. Eat rum balls. Watch the snow.

\author{
Not twinkling lights \\ we see but \\ search lights \\ seeking illegal aliens \\ outside our thick windows.
}

In this poem, one can clearly observe how the spacing indicates a confrontation, and how the heteroglossia is produced not only through the mixture of English and Spanish, but also through the different registers of English, one appearing to be stilted or translated. Though we often resorted to the convention of italics to signal the bilingualism - Mora herself employs italics for the Spanish she includes-the linguistic tension is not the same. A simple inversion of the Spanish and English cannot suffice because it would lose the entire bilingual speech act's veracity. Here, the decision to leave specific words in English responds to our desire to reaffirm the compelling bicultural dynamics and hierarchies that constitute this poem, which is not a process of code switching but of synecdochic and dialogic configuration. Furthermore, in this particular text, there is an intertextuality arising from a popular Christmas song in the epigraph, which both establishes the holiday setting and poses the ontological problem dramatized by the poem: "do you hear what I hear?" suggesting that significance is in the mind and culture of the beholder.

The first line is a common greeting and farewell in Spanish, and in the third there is an interpellant voice directed to those who have spoken in Spanish: "Stop flinching. Drink eggnog. Hum along." After this there is a greatly indented strophe, written in an 
unusual register to represent the Latino voice in English: "Not carols we hear," which would normally be, "we aren't listening to carols." With this new voice, Mora establishes a heteroglossia that signals the cultural conflict between the "Anglos" and the "Latinos" in their divergent appreciation of Christmas, particularly in this frosty and alien environment.

The third stanza incorporates another line from the same song, "Do you see what I see?" so as to question the attempted integrative atmosphere of the office: "slight Southof-the border seasoning" which is the token gesture of the Anglo, who will then try out a few phrases in Spanish. However, his/her suggestion that they enjoy the snow and traditional fare of rum balls and eggnog is answered by the other voice once again. In our version, we tried to capture the stilted speech in the hope that the unusual character of the register might be conveyed in these two indented strophes, which sound much like a soliloquy of thoughts murmured under one's breath:

Nada del titilar de lucecitas
sino reflectores
vemos
a la busca de ilegales
más allá de este doble vidrio.

The idiomatic strain represented in the poem demands careful selection so as to produce the same effect on the Spanish reader. Thus, the decision to leave the culturemes of "eggnog," "rum balls," and "snow" in the Spanish version is the result of our desire to reaffirm the culture clash with elements "other" to the Mexican sensibility since these words are essential and exclusive to the U.S. Christmas tradition: "No sean cobardes. Tomen eggnog. Tarareen con nosotros." "Relájense. Coman rum balls. Miren, snow."

Of course, the intertextuality of the song gets lost because the melody does not form part of the popular Hispanic imaginary, even if the words are understood, which is most probable since they are quite elementary. Songs, nicknames, and idiomatic phrases are highly charged, cultural-specific factors in literature, which place an accent on identity and often defy translation. In representing their bicultural reality, Latino poets constantly include these elements in their works. Placing the lines of this song in italics and in English helps to deepen the linguistic fissure, but cannot produce the significance of the Christmas carol tradition. 
Another related conflictive category lies in figures derived from the very vocalization of each language such as euphony, puns and onomatopoeia. In general, due to its vast amount of spelling rules and openness to change, English is a language that permits frequent wordplay in the form of homonyms, compound words, kennings and neologisms, much of which is impossible to render in the relative inflexibility of Spanish.

The images produced by onomatopoeia are particularly difficult in English-toSpanish translations. English has many more words to represent sounds and in the poem "Los amantes" by Richard García, the click clack of the dancing steps and the words that sound like clattering bones present a tremendous challenge to the translator:

We click clack up down escalators.

You rattle around me

taking tiny elegant steps,

whisking your skirt from side to side

as if to fan the flames

my feet stamp out.

In Spanish, we rendered these lines as follows:

Subimos clic clac escaleras mecánicas que bajan.

Entrechocar traqueteo

con tus pasitos elegantes,

agitando tu pollera de un costado a otro

como para avivar las llamas

que sofoco con mis pasos.

"Subimos clic clac escaleras mecánicas que bajan. / Entrechocar traqueteo" proved to be a fortunate invention for the emulation of the marionettes' movements, but not every line found such a happy solution. The last line cited, for instance, "my feet stamp out", composed of monosyllabic words that represent the stomping, could not be reproduced in our translation. Furthermore, as phrasal verbs do not exist in Spanish, the economy of the line is lost as well.

García, as do most other poets of our selection, utilizes a wide range of literary elements inherent to both English and Spanish conventions in his work while mixing cultural components such as those of the skeleton marionettes of the Mexican tradition 
represented in this poem. Conjoining both his Puerto Rican and Mexican heritage with his English education, García explores family and romantic relationships, often using montage to juxtapose striking episodes to construct poems whose effects vacillate between humor and perplexity in his contemplation of the curious structures and coincidences of reality. A good illustration is "Note Folded Thirteen Ways." In this poem there arises a different problem of intertextuality, due to the allusion to Wallace Stevens' "Thirteen Ways of Looking at a Blackbird." In our attempt to ensure recognition of this reference, we tried to find out how the title of the Stevens poem had been translated into Spanish, but discovered eight different ways (almost 13 ways!), so we could offer no guarantee regarding the Spanish reader's access to this allusion.

As regards sonority and euphony of this verse, the rhythms and metrics of the two languages are quite dissimilar, so the recreation of musical rhythms or lyrical conventions can prove difficult if not impossible. Since Spanish words usually contain more syllables than English ones, the translation of a sonnet, for instance, requires the omission of words in order to endow the new version with the traditional patterning, as was the case in Rafael Campo's "Sonnet in the Cuban Way." A physician of Cuban parents, Campo is an admirer of classical forms of English literature and tends to create rhythms and rhymes to intertwine his political, social and biological topics. In the poem cited, we attempted to reproduce the lines with Alexandrians-12-syllable lines-to render the poetics of this author, who has a great flare for rhyme and rhythm and thus deserves special metrical attention:

To make you fall in love with me, I'd curse

Before I'd sing to you; implacable

And elegant, I'd force you with my class

Beneath a music kind of tropical

But mine enough you'd never recognize

Its foreign cadences. $\mathrm{O}$ island whore,

I'd stare like moonlight in your eyes,

I'd lie that I don't want you anymore

Then fuck you like Americans know how-

To make you fall in love with me, I'd die

Just near enough to you there' $\mathrm{d}$ be no doubt

My feelings are eternal. Dressed in dew,

You'd meekly pardon my brutality,

In love at last, so naked you'd seem free. 
Campo plays with the unexpected combination of flamboyant Cuban rhythms and imagery with the conservative conventions of the English sonnet tradition. Though our Spanish version does not rhyme, we developed an 11-syllable metrical pattern for the 14 lines, which is only broken in line six. As the original line also presents a strident fracture in the sonnet love tradition in the English version - "Its foreign cadences. $\mathrm{O}$ island whore," - we felt a disruption was justified in the Spanish version. It is this incongruence we felt had to be encapsulated in the translation, so the metrical rupture in the Spanish serves to highlight this break with decorum:

\section{Soneto al modo cubano}

Para que te enamores de mí, yo antes

de cantarte, insultaría; implacable

y elegante, te forzaría con mi clase

bajo una música algo tropical

pero bastante mía para que nunca

reconocieras su cadencia extranjera. Oh isla puta,

como luz de luna miraría tus ojos,

mentiría que no te quiero más, luego

te cogería con American know-how-

para que te enamores de mí, moriría

bastante cerca de ti, que no haya dudas:

eterna es mi pasión. Mansa y vestida de

rocío, perdonarías mi brutalidad;

enamorada, desnuda lucirías tu libertad.

In an attempt to underscore the heteroglossia, we used an English phrase in lieu of the pun on "know how": "Then fuck you like Americans know how" we rendered as "te cogería con American know-how," an expression synonymous with the U.S. work ethic and progress. We then closed the poem with a rhyming couplet to reinforce the poem's euphony and compensate for the loss of the sonnet's rhyme scheme.

The need to maintain the original non-Argentine Spanish in specific texts led to a difficult mixture of techniques in the poem "Abuelo. Answers and Questions" by Colombian-born poet Maurice Kilwein Guevara:

1. 
Abuelo, why are there flies?

They're reporters for the dead, mi joven bestia.

What do they report?

If the millonarios won or lost.

$[\ldots]$

3.

Abuelo, who puts the scorpion in my bed when I'm asleep?

Why, is there one when you wake?

Yes.

Dead?

Yes.

Don't worry. The dead don't sting.

Guevara's use of italics to signal the grandfather's speech forced us to use regular print for the intercalated instances of heterolingualism and of Colombian references such as the soccer team, "millonarios." Furthermore, the grandfather would not be using the "vos" form to talk to his U.S. grandson, so the verbs were conjugated with the "tú" form: "¿Hay uno cuando te despiertas?"

Abuelo, respuestas y preguntas

1.

Abuelo, ¿por qué hay moscas?

Traen noticias de los muertos, silly boy.

¿Qué noticias traen?

Si los millonarios ganaron o perdieron.

$[\ldots]$

3.

Abuelo, ¿quién mete el escorpión en mi cama cuando duermo?

¿Por qué? ¿Hay uno cuando te despiertas?

Sí.

¿Muerto?

Sí.

No te preocupes. Los muertos no pican.

This poem is just one example of how our best intentions of systematization were shattered by the heteroglossic strategies of the poet. Here, both the grandfather's words 
and the boy's name for his grandfather, "abuelo," stand in italics, leading to a bit of confusion in the overall effect of the use of italics in the anthology.

\section{In Summation: a Balance Sheet}

After discussing our dilemmas, decisions and failures, most of our initial problems have been addressed: Are all instances of heterolingualism transferrable? What can one do so as to maintain a cultureme? Is it enough to add an artistic "seasoning" to mark a duality present? However, one further issue remains: should all heterolingual texts be translated, considering their strategy of resisting normative discourse?

David Colón maintains: "The poetics of the other is the modality of confusion; it is a blurring of the dimensions and domains of language. Latino poetics are conducted in otherhood. [...] [T]he voice of the other is the voice of unintelligibility." (284, 269). As an example we have the now emblematic work of Gloria Anzaldúa, Borderlands/La frontera, which has been cited by many postcolonial critics to illustrate successful practices of hybridity. This Chicana writer creates an attractive, but extremely privileged vision that juxtaposes languages and genres in order to represent the interstices of the border. Here, the angle of privilege has been shifted to favor the multilingual reader, but this text has not and perhaps could or should not be translated.

Other critics maintain, nevertheless, that it is essential to translate these texts into Spanish since it is the best way to reunite them with their cultural roots and thus perpetuate the migratory visions of these writers ${ }^{7}$. Moreover, the translation of these excentric works has become a profitable enterprise owing to their present popularity and relevance. The poets of our compendium demonstrated great enthusiasm regarding their reentry into the Hispanic domain; in fact, one poet, Silvia Curbelo, has given various readings that include our versions of her works.

Yet, the quandary lingers on: how can a translator arrive at a recognizable convention, a translation norm to reproduce the negation of normative discourse? Lyrical expression tends to twist normative discourse, reinventing it so as to expand and play with reader perception; in the case of many Latino poets, there is a double twist since they often deterritorialize the English language. While representing their bicultural experience through intentional linguistic transfers, they undermine the monolingualism imposed by the U.S. During our work with these Latino poets, we had

\footnotetext{
7 See Raquel Merino Álvarez.
} 
hoped to arrive at systematic solutions to translating heteroglossia-omission in lines of self-translation, italics in titles, the recreation of dialogic modes, Caribbean or Mexican usage in actual dialogues, synecdochic compensation, Argentine colloquial languagebut we soon found that each poem demanded its own solution. A Spanish translation of this verse is forced to participate in a multifarious rendition in order to retranslate the normative discourse being challenged, as was seen, for example, in Mora's "Bilingual Christmas." Perhaps the proliferation of similar mixed-technique translations will function in an intercalated fashion akin to that of the original and will thus be judged as successful in the future.

The heteroglossia of these poets is, in the end, as much an artistic ploy as an ideology portrayed, and while their discourse may reflect real world usage, they use a technique of synecdochic interpolation in most cases. Therefore, when the poetic discourse is a crafting of the two languages rather than an attempt at actual speech, as one finds in many of our poems, a compensating synecdoche would seem to suffice to render their heteroglossia. These texts - with all their resistant gaps - can be understood by the monolingual English reader since there is neither an indigenization of the English nor an overriding use of Spanish. Their heterolingual strategy, moreover, does not participate in the elitist bias of Modernism or the untranslatability of Anzaldúa's text. Perhaps this method can be viewed as a sign of their striving to communicate with the Anglo establishment without sacrificing their second culture, a common convention of contemporary multicultural expression. Nevertheless, the general move in literature from a non-factional to an artistic factionality derived from a postmodern or postcolonial use of heteroglossia bespeaks both the subversive and the artistic bias of heterolingual poetry, as can be observed from this Latino verse. One can only hope that both the artistry and the social commentary of the language politics are captured in the translation, a process that depends as much on the translation as on the new readership. Therefore, both translators and readers need to be remolded if they are to understand and enjoy the multicultural experience in lieu of relegating it to the realm of "minor" or untranslatable literature.

A renovation of literary studies has become one of the major concerns of Comparative Literature in the last 10 years, to which Translation Studies has greatly contributed. In writing about the need to rethink and revamp Comparative Literature, Gayatri Chakravorty Spivak in Death of a Discipline recommends a type of teaching of literature and language that would reveal the irreducible hybridity of every language in order to understand the "performativity" of cultures - that is, a dialogical and dramatic mode whose meaning depends on its reception. Instead of utilizing a method to teach 
the "transcoding" of a text, she promotes one that would prepare a reader's imagination for the effort to "other" the response to a given text. As she most pithily states: "The verbal text is jealous of its linguistic signature but impatient of national identity. Translation flourishes by virtue of that paradox" (9).

We have, with this anthology, strived to maintain the dynamic diversity of these poems in order to promote a richer, postnational reading through translation. In our attempt to enact a "transformance" of these poets' "interanimation of languages," we employed a variety of strategies - italics, bilingualism, a preface and en face bilingual printing - in search of a bilanguaged re-presentation that would provoke new uses of the imagination, as slippery as the going may be. To quote Mignolo once again:

Bilanguaging would then be the movable ground on which educational projects and the decolonization of scholarship can be located; where the complicity between colonial languages and scholarship could be rethought; where Babel may not be as bad as the ideologues of unification and the purity of blood and language thought it was. (277)

Translation is a phantasmagorical bridge we traverse, loaded down with words stuffed into the knapsacks of our imaginations, where our cerebral magicians convert our cargo into something that looks and sounds entirely different from how it seemed before; though, once again on the solid ground of a new culture, these recontextualized conversions can often create scenes that will arouse astoundingly similar human responses. In translating these Latino poets into Spanish, we have endeavored to perform a reenactment of their wit in order to regenerate the movable ground of heteroglossia and the bicultural realities embodied in their poetry and, in so doing, reconnect them to the Spanish-speaking world. 


\section{REFERENCES}

Álvarez Caccamo, Celso. "Introduction: Class and ideology in code-switching research.” Jan. 5, 2007 http://www.udc. es/dep/lx/cac/artigos/sib2002.htm

Anzaldúa, Gloria. Borderlands/La Frontera: The New Mestiza. San Francisco: Spinsters / Aunt Lute, 1987.

Ashcroft, Bill, Gareth Griffiths and Helen Tiffin. The Empire Writes Back: Theory and Practice in Post-Colonial Literature. London: Routledge, 1989.

Bandia, Paul. "Code-switching and code mixing in African creative writing. Some insights for Translation Studies." TTR 9-1 (1996): 139-153.

----------. Translation as Reparation. Writing and Translation in Postcolonial Africa. Manchester: St. Jerome, 2008.

Bakhtin, Mikhail. The Dialogic Imagination. Translated by Vadim Liapunov. Austin: U. of Texas Press, 1981.

Bhabha, Homi. The Location of Culture. New York: Routledge, 1992.

Bradford, Lisa Rose. "La 'visión migratoria': de Kim a El paciente inglés." Aristas 2 (2004): 109128.

Bradford, Lisa Rose and Iriarte, Fabián, eds. Usos de la imaginación: poesía de l@s latin@sen EE.UU. Mar del Plata: EUDEM, 2009.

Campo, Rafael. Diva. Durham: Duke U.P., 1999

Colón, David. “Other Latino Poetic Method." CulturalCritique 47 (2007): 266-86.

Derrida, Jacques. El monolingüismo del otro. Buenos Aires: Manantial, 1997.

García, Richard. The Flying Garcías. Pittsburgh: University of Pittsburgh Press, 1993.

Guevara, Maurice Kilwein. Postmortem. Athens: University of Georgia Press, 1994

Grutman, Rainier. "Refraction and recognition literary multilingualism in translation." Target 18.2 (2006): 17-47.

Kessler, Stephen. After Modigliani. Berkeley: Creative Arts, 2000.

Merino Álvarez, Raquel. "Traducción y literatura chicana: Miguel Méndez traducido." Literatura chicana. Reflexiones y ensayos críticos. Rosa Morilla Sánchez and Manuel Villar Raso, eds. Granada, 2000 : 263-271.

Mignolo, Walter. Local Histories/Global Designs. Princeton: Princeton UP, 2006.

Mora, Pat. Borders. Houston: Arte Publico Press, 1986.

Ngugi wa Thiongo. Decolonizing the Mind: The Politics of Language in African Literature. London: Currey, 1986.

Nord, Christiane. Translating as a purposeful activity: functionalist approaches explained. Manchester: St. Jerome, 1997.

Schendl, Herbert. "Hec sunt prata to wassingwellan': aspects of code-switching in Old English Charters." Historical Sociolinguistics and Sociohistorical Linguistics. 2005. Leiden University. Feb. 9, 2007 http://www.let.leidenuniv.nl/hsl shl/code\%20switching\%20in\%20oe.htm

Soto, Gary. New and Selected Poems. San Francisco: Chronicle Books, 1995. 
http://ejournals.library.ualberta.ca/index.php/TC

Spivak, Gayatri Chakravorty. Death of a Discipline. NY: Columbia UP, 2006.

Steinberger, Meir. "Polylingualism as Reality and Translation as Mimesis." Poetics Today 2.4 (1981): 221-239.

Tylor, Elizabeth M. "Talking about history in eleventh-century England: the Encomium Emmae Reginae and the court of Harthacnut." Early Medieval Europe. Oxford: Blackwell Publishing U.K. (2005): 359-383.

Zughoul, Muhammad Raji and El Badarien, Mohammed. “Diglossia in Literary Translation: Accommodation into Translation Theory." Jan. 10, 2007. http://www.erudit.org/revue/meta/2004/v49/n2/009369ar.html. 